\title{
Playing Across Borders: Transnational Sports and Identities in Southern California and Mexico, 1930-1945
}

\author{
JOSÉ M. ALAMILLO
}

The author is a member of the Chicana/o studies program at California State University, Channel Islands.

This article examines the local and transnational dimensions of sports in Southern California through the activities of the Mexican Athletic Association of Southern California (MAASC) from the Great Depression to the end of World War II. This amateur athletic organization promoted sports in the barrios and colonias throughout Southern California and forged transnational ties with the Mexican government and its sports federation. MAASC and its related activities reflected two competing historical trajectories that have been subjects of debate in Chicano historiography. MAASC sports simultaneously reinvigorated transnational ties with Mexico that emphasized a México de afuera identity and contributed to the making of a Mexican American identity that connected immigrants to Southern California and American society in general. Ultimately, both impulses helped to instill a new political confidence among MAASC members to challenge the Los Angeles Department of Playground and Recreation's paternalistic approach toward the Mexican community.

José Arteaga was born in Baja California, Mexico, moved to Los Angeles during his teen years, and in 1921 teamed up with Lamberto Alvarez Gayou to form the first all-Mexican basketball team, "Bohemia." Gayou eventually became the president of Mexico's first sports federation, and Arteaga became a basketball player and coach in the city's new amateur athletic association. Arteaga coached several teams, with only the best players chosen to play exhibition games in Mexico. His criteria for selecting his all-star Mexican basketball team included height and weight standards (a minimum height of 5 feet 8 inches, weight of less than 160 pounds), good sportsmanship, technical knowledge and ability, and "patriotism and love for Mexico." On the last requirement,

Pacific Historical Review, Vol. 79, No. 3, pages 360-392. ISSN 0030-8684

(C) 2010 by the Regents of the University of California. All rights reserved.

Please direct all requests for permission to photocopy or reproduce article content through the 
Arteaga praised his players as "representing the sporting spirit of México de afuera."

Like Arteaga, Juan Acevedo was another amateur athlete who sought to increase recreational opportunities for Mexican-origin youth. Acevedo was born in East Los Angeles and became a star cross-country runner at Roosevelt High School and Los Angeles City College. Between 1933 and 1936 Acevedo held the city's threemile record (17 minutes and 20 seconds). Unlike Arteaga, however, Acevedo advocated for the use of the term "Mexican American" because "racism toward Mexicans was deeply rooted [in the United States] ... we had to confront the reality of our situation [and] call attention to our U.S. citizenship." ${ }^{2}$ These two athletes, Arteaga and Acevedo, had different ideologies that co-existed within the new amateur athletic association called the Mexican Athletic Association of Southern California (MAASC).

This article examines the local and transnational politics of sports in Southern California and Mexico through the activities of MAASC from the 1932 Olympic Games up until World War II. The 1932 Olympic Games in Los Angeles provided an opportunity to bring city recreation officials, Mexican government representatives, and Mexican and Mexican American leaders together to form an amateur athletics organization to promote sports in the barrios and colonias of Southern California. MAASC organized sports leagues, tournaments, and exhibition matches; it also secured recreation facilities, provided entertainment, and offered other athletic opportunities. A unique feature of MAASC was its transnational ties with the Mexican government's sports federation, the Confederación Deportiva Mexicana (CDM). This article argues that MAASC and its related activities encouraged two historical trends that have been subjects of debate in Chicano historiography. MAASC sports forged transnational ties with Mexico that allowed some athletes to adopt a Mexican national identity outside of Mexico and others to adopt a Mexican American identity that connected them more closely with Southern California and American society in general. Ultimately, these were simultaneous, rather than sequential, processes that helped to instill a new political confidence among MAASC members in the face of the paternalistic

1. La Opinión, April 26, 1933, p. 4; ibid., April 20, 1933, p. 4. All translations from Spanish are by the author.

2. Mario García, Memories of Chicano History: Life and Narrative of Bert Corona (Berkeley, 1994), 83. 
approach of the Los Angeles Department of Playground and Recreation (LADPR) toward the Mexican-origin population.

Scholars have developed a rich historiography on Chicano Los Angeles, the largest Mexican metropolis in the United States. One historical trajectory has emphasized the process of "becoming" Mexican American. The leading proponent of this view, historian George Sánchez, has argued that, despite a lack of social mobility, "The struggle which forged a Mexican American identity was powerfully rooted in the decade of the 1930s." Sánchez briefly mentions that "Young men were more likely to seek out new leisuretime activities, such as American sports." Another historical trajectory stresses the process of how immigrants from Mexico became "Mexicans" in México de afuera. The term "México de afuera" refers to Mexican communities residing outside of Mexico whose members sought to recreate a sense of Mexicanidad through art, religion, festivals, theater, and sports. The leading proponent of the second trajectory, historian Douglas Monroy, has argued that immigrants from different regions of Mexico were "reborn" as "Mexicans" in pre-World War II Los Angeles. ${ }^{4}$ Sports, Monroy contends, "was one way the various people from south of the border forged an identity as Mexicans, a way for Mexicans to garner respect in the eyes of the americanos." ${ }^{5}$ Both historical trajectories occurred simultaneously in MAASC and its related activities. Thus, this article supports the arguments of both Sánchez and Monroy.

The rise of the "new" social history and cultural studies has spurred academic interest in sports in America's cities. Sports provided a sense of community for immigrants who faced an alienating urban environment. For children of immigrants, sports played a key role in their adjustment to American society while also helping to maintain their ethnic identity. Most urban sports studies, however, have remained focused on European Americans

3. George J. Sánchez, Becoming Mexican American: Ethnicity, Culture and Identity in Chicano Los Angeles, 1900-1945 (New York, 1993), 12, 173.

4. Douglas Monroy, Rebirth: Mexican Los Angeles from the Great Migration to the Great Depression (Berkeley, 1999). Mexicans in Chicago also became "Mexican" outside of the nation-state of Mexico. See Gabriela Arredondo, Mexican Chicago: Race, Identity, and Nation, 1916-1939 (Urbana, Ill., 2008), and Rick Lopez, "Forging a Mexican National Identity in Chicago: Mexican Migrants and Hull-House, 1920-1937," in Cheryl R. Ganz and Margaret Strobel, eds., Pots of Promise: Mexicans, Reformers, and the HullHouse Kilns, Chicago, 1920-1940 (Chicago, 2004).

5. Monroy, Rebirth, 47. 
and African Americans. ${ }^{6}$ Although Latinos have participated in a wider range of sports, the few scholarly books on Latino sports have focused primarily on baseball. ${ }^{7}$ At the same time, in major studies of Chicano Los Angeles, historians have focused on mutual aid societies, labor unions, student and religious groups, consular commissions, civil rights organizations, and legal defense committees. ${ }^{8}$ Recreation and sports clubs have been largely ignored, even though over twenty-five existed in California before 1930 and "served to bring the community closer together." To understand the significance of sports on both sides of the U.S.-Mexican border, scholars "must shed national identities in conjunction with turning in [their] disciplinary passports." The interdisciplinary field of transnational studies has much to offer Chicano sports history. ${ }^{9}$ Compared to other Chicano voluntary organizations, MAASC was

6. S. W. Pope, ed., The New American Sport History: Recent Approaches and Perspectives (Urbana, Ill., 1996), 3-21; Stephen Hardy, How Boston Played: Sport, Recreation, and Community, 1865-1915 (Boston, 1982); Melvin Adelman, A Sporting Time: New York City and the Rise of Modern Athletics, 1820-1870 (Urbana, Ill., 1986); Gerald Gems, The Windy City Wars: Labor, Leisure, and Sport in the Making of Chicago (Lanham, Md., 1997); Steven Riess, City Games: The Evolution of American Urban Society and the Rise of Sports (Urbana, Ill., 1989), 93-123; Jeffrey T. Sammons, "'Race' and Sport: A Critical, Historical Examination," Journal of Sport History, 21 (1994), 203-277.

7. Samuel O. Regalado, Viva Baseball! Latin Major Leaguers and Their Special Hunger (Urbana, Ill., 1998); Alan Klein, Baseball on the Border: A Tale of Two Laredos (Princeton, N.J., 1997); Adrian Burgos, Jr., Playing America's Game: Baseball, Latinos, and the Color Line (Berkeley, 2007); José Alamillo, "Peloteros in Paradise: Mexican American Baseball and Oppositional Politics in Southern California, 1930-1950," in Jorge Iber and Samuel O. Regalado, eds., Mexican Americans and Sports: A Reader on Athletics and Barrio Life (College Station, Tex., 2007).

8. Jose Amaro Hernandez, Mutual Aid for Survival: The Case of Mexican Americans (Malabar, Fla., 1983); Francisco E. Balderrama, In Defense of La Raza, the Los Angeles Mexican Consulate, and the Mexican Community, 1929 to 1936 (Tucson, Ariz., 1982); Vicki L. Ruiz, Cannery Women, Cannery Lives: Mexican Women, Unionization, and the California Food Processing Industry, 1930-1950 (Albuquerque, 1987); Gilbert G. González, Mexican Consuls and Labor Organizing: Imperial Politics in the American Southwest (Austin, Tex., 1999); Edward J. Escobar, Race, Police, and the Making of a Political Identity: Mexican Americans and the Los Angeles Police Department, 1900-1945 (Berkeley, 1999); Matt García, A World of its Own: Race, Labor and Citrus in the Making of Greater Los Angeles, 1900-1970 (Chapel Hill, N.C., 2001).

9. Nelson Pichardo, "The Establishment and Development of Chicano Voluntary Associations in California, 1900-1930," Aztlán: Journal of Chicano Studies, 19 (1992), 106; Alan Klein, "Towards a Transnational Sports Studies," Sport in Society, 10 (2007), 885. The concept of transnationalism has been applied to the arena of politics, economics, the social, the cultural, and the religious. Peggy Levitt and Nadya Jaworsky, "Transnational Migration Studies: Past Developments and Future Trends," Annual Review of Sociology, 33 (2007), 139-156. 
unique in forging transnational ties with the Mexican government and its sports movement. ${ }^{10}$ The association built a transnational network of coaches, managers, promoters, and athletes that linked the development of Mexican American sports in Los Angeles with the rise of sports in Mexico. Nevertheless, sports organizations like MAASC had a gender bias. Like contemporary hometown associations, Mexican men used sports organizations to enhance their political status in relation to the Mexican state while excluding women from leadership positions and "manly" sports. ${ }^{11}$

\section{The 1932 Olympic Games}

The idea of an amateur athletic association for the Mexican community in Los Angeles originated months prior to the 1932 Olympic Games. Despite a worldwide economic depression, the Los Angeles Olympic Organizing Committee ignored calls for cancellation and pressed ahead to stage the world's biggest sporting event. Foreign countries faced financial difficulties in sending their athletes to Los Angeles. Mexico, which had made its Olympic debut in 1924, reached out to México de afuera for assistance. Mexico's official Olympic committee appointed Enrique Mexia, a commercial agent for the Mexican government (whose office was located inside the Los Angeles Chamber of Commerce building) to form a subcommittee with local businessmen and professionals to raise funds for Mexico's Olympic team. ${ }^{12}$ The new subcommittee was named the Mexican-American Olympic Committee (MAOC), and its first action was to appeal to the patriotism of readers of La Opinion: "What a beautiful opportunity to show our government officials and

10. Gustavo Cano and Alexandra Delano, "The Mexican Government and Organised Mexican Immigrants in the United States: A Historical Analysis of Political Transnationalism (1848-2005)," Journal of Ethnic and Migration Studies, 33 (2007), $695-725$.

11. Luin Goldring, "Gender, Status, and the State in Transnational Spaces: The Gendering of Political Participation and Mexican Hometown Associations," in Pierrette Hondagneu-Sotelo, ed., Gender and U.S. Immigration: Contemporary Trends (Berkeley, 2003), 341-358.

12. The Mexican Olympic Committee of Los Angeles was comprised of Joaquin Terrazas, Mexican consul of Los Angeles; Mauricio Calderon, music promoter; Jesus Monjaras, medical doctor; Lamberto Hernandez, businessman; Miguel Bracho, radio announcer; Juan Aguirre Delgado, engineer; Moises Sáenz, college professor; Miguel Ramirez, businessman; Alfonso Rojo de la Vega, businessman; and I. F. Herrerias, sports writer. La Opinión, Oct. 21, 1931, p. 4. 
compatriots that live in Mexico that the dividing line and distance are purely geographic because, when it comes to uniting our people, we help out with such big endeavors in the name of Mexico." Mexia urged compatriots to purchase a one cent "Mexican Olympic Stamp" from Mexican-owned businesses or from female contestants competing for the title of Mexican Olympic Queen. He also instructed readers to place the stamps on their house and car windows as a "symbol of solidarity with La Raza."13

Despite nationalist appeals, Mexia encountered problems raising money from a community suffering high unemployment and nativist hysteria. Mexia recruited prominent Anglo Californians as honorary members, including Governor James Rolph, city mayor John Porter, Hollywood cowboy star Will Rogers, Los Angeles Times publisher Harry Chandler, and superintendent of the Los Angeles Department of Playground and Recreation (LADPR) Raymond Hoyt. Mexia also solicited help from recreational clubs and athletic organizations in Mexican communities. Fernando Miranda, president of the Bohemia Athletic Club, responded to Mexia's call by convening a meeting with his members at Evergreen Playground. Bohemia proposed an exhibition event modeled on the Olympic Games, with over twenty-five athletic clubs competing. Mexia and Miranda approached Superintendent Hoyt for financial support. Hoyt enthusiastically supported the request and instructed his employees to publicize this "special athletic program to be held at Evergreen Playground on May 8th." The "Mexican pre-Olympic event" was declared a "big success," attracting over 300 spectators and 100 athletes competing in different track-and-field events, with each champion earning an Olympic-like medal. ${ }^{14}$ Besides defraying the costs for the visiting Mexican Olympians, the participating athletic clubs used the event to seek additional support from the city recreation department.

To generate additional funds, MAOC announced a special contest for local amateur boxers of Mexican descent. According to Mexia, five winners would be ensured a spot in Mexico's Olympic boxing squad for the 1932 Olympics. After receiving approval

13. Ibid., April 28, 1932, p. 5; ibid., April 29, 1932, p. 4

14. Los Angeles Times, April 22, 1932, p. A18; La Opinión, April 17, 1932, p. 4; Weekly Bulletin, April 15, 1932, p. 3, folder C-2010, box 70, Records of the Los Angeles Playground and Recreation Department, Los Angeles City Archives, Los Angeles (hereafter LADPR Records). 
from the state boxing commissioner and the Los Angeles Athletic Club, the pre-Olympic boxing tournament was held at the Olympic Auditorium on July 11, 1932. The Los Angeles Times reported that "Several amateur scrappers from Old Mexico are here to compete against the best Mexicans of Southern California for the five positions on the Mexican ring squad." 15

This contest generated so much excitement that another one was held for track-and-field athletes at White Sox Park. Attendees paid twenty-five cents to watch athletes from Baja California compete in eleven track-and-field events against local athletes from Southern California. Nicknamed the "Mexican Olympic Fiesta" by the Los Angeles Times, this pre-Olympic event featured a night baseball game, a Mexican army band performance, the crowning of the Mexican Olympic Queen, and a guest appearance by Mexican Hollywood actress, Lupita Tovar. ${ }^{16}$ In a letter to Superintendent Hoyt and LADPR commissioners, Mexia expressed his appreciation: "We wish to thank you for your most splendid cooperation given to our [Mexican-American Olympic] Committee for the meet between Los Angeles and Lower California Mexican athletes at the White Sox Park." 17

By the time the Mexican Olympians arrived on July 23, 1932, MAOC had raised over $\$ 3,000$. Fifty-two Mexican athletes, officials, and coaches were escorted to the Olympic Village in Baldwin Hills by a caravan of 600 automobiles and were greeted by 5,000 spectators lined up along Crenshaw and Vernon avenues, waving Mexican flags. That same night a special dinner and dance were held at the Shrine Auditorium, hosted by MAOC, the Mexican Olympic Queen, and "more than 600 Mexican athletes, members of Southern California athletic associations." 18

Despite all the fanfare and excitement, the Los Angeles Times relied on a series of racial stereotypes to describe the visiting athletes. One article described them as "Mexican caballeros [who] bring color to [the Olympic] village," carrying "the blood of the Aztecs and the Continental Spanish in their veins" and enjoying a strict diet of "frijoles." Racialized images of "frijole-eating" athletes

15. Los Angeles Times, July 11, 1932, p. 9.

16. La Opinión, June 6, 1932, p. 3.

17. Meeting Minutes, Records of the Board of Playground and Recreation Commissioners, June 15, 1932, p. 776, folder C-0368, box 70, LADPR Records.

18. Los Angeles Times, June 11, 1932, p. A3. 
did not surprise Mexican American leaders who were already feeling besieged by a climate of racial discrimination. According to the newspaper, "The Mexican Olympic forces were a bit surprised and the local Mexican papers are indignant, over reports that the ever-popular frijole bean is the predominant dish in the training diet of the visitors from the neighboring republic. The only thing conspicuous about the frijoles in the Mexican camp is their absence, the athletes say." Despite the negative press, the Mexican Olympic athletes received strong support from Mexican American fans during the games. They won silver medals in boxing and shooting. In a show of trasnational solidarity, the Mexican Olympic team invited athletes from México de afuera to accompany them as they circled the Coliseum waving the Mexican flag during closing ceremonies. ${ }^{19}$

The international appeal of the Olympic Games offered an opportunity for immigrant groups in Los Angeles to display their ethnic nationalism by hosting and cheering for their compatriots. ${ }^{20}$ Like the Los Angeles Japanese Association, the MAOC hosted, entertained, and cheered for visiting Olympic athletes from their homeland. ${ }^{21}$ The Mexican government, however, sought to recruit athletic talent from México de afuera to achieve Olympic victory on the international stage. The Los Angeles Times observed that "Names rather familiar to Southern California sport fans are found on the list of athletes who will represent old Mexico in the Olympic Games. Six boxers and five track men all received their preliminary athletic training at Southland high schools." ${ }^{22}$ One of these athletes was Los Angeles-born Midget Martinez, who, after winning the flyweight division in the pre-Olympic boxing tournament, earned a spot on Mexico's boxing team. Several years later Martinez served as the amateur boxing sport commissioner for MAASC.

19. Ibid., July 23, 1932, p. 9; ibid., July 22, 1932, p. A10; ibid., July 29, 1932, p. A14; La Opinión, Nov. 27, 1932, p. 3.

20. Barbara J. Keys, Globalizing Sport: National Rivalry and International Community in the 1930s (Cambridge, Mass., 2006), 3-4.

21. Eriko Yamamoto, "Cheers for Japanese Athletes: The 1932 Los Angeles Olympics and the Japanese American Community," Pacific Historical Review, 69 (2000), 399-430.

22. Los Angeles Times, July 21, 1932, p. A10. The athletes included six boxers (Ray Campo, Al Romero, Ernie Jurado, Midget Martinez, Sammy Garcia, and Carl Gallardo) and five track-and-field runners (Alfredo Gamboa, Emilio Rodriguez, Fernando Ortiz, Pablo Ortiz, and Dick Arguello). 
One cannot overestimate the significance of the Olympics in spurring athletic interest in the expatriate community. Labor and civil rights leader Bert Corona later recalled, "The Olympics in 1932 had also attracted many Mexicanos, especially to see the Mexican and Mexican-American athletes who participated in the running events." ${ }^{23}$ In a letter to Mexican President Abelardo Rodríguez, the president of Club Atletico México expressed such excitement in watching his "paisanos" compete in the Olympics that he offered to "bring his basketball team to beloved Mexico for a tour to lift up the sporting spirit of his brothers and to help them prepare for the next Olympics [in Berlin]."24 The Olympics Games brought together Los Angeles city officials, Mexican government representatives, and local athletic clubs for the first time, laying the groundwork for a new amateur association to coordinate and promote athletic events throughout Southern California's barrios and colonias.

\section{The Mexican Athletic Association of Southern California}

Three months after the Olympics, MAASC held its first meeting in the LADPR office to approve a new constitution, organizational structure, and executive board. Its constitution outlined its main objectives:

(1) The object of this association shall be to organize, conduct, and promote the physical and cultural, social intercourse and recreational athletic activities in Latin-American communities in accordance with the rules of the Amateur Athletic Union of America. (2) To unite, co-ordinate, and enlarge the athletic programs of the Latin-American communities. (3) To advance and improve amateur athletic relations between the United States and Mexico (4) To inculcate the spirit of true sportsmanship among Latin-Americans and to bring greater co-operation among the organizations, thereby fostering fellowship and goodwill among them and the community in general. ${ }^{25}$

23. García, Memories of Chicano History, 85.

24. Ramón Sanchez to Abelardo Rodríguez, Oct. 24, 1932, Abelardo Rodríguez Papers, ALR 332.3/355, Archivo General de la Nación, Mexico City (hereafter Archivo General).

25. Articles of Incorporation, Southern California Mexican Athletic Association, p. 1, folder 14, box 4, MO295, Manuel Ruiz Papers, Special Collections, Green Library, Stanford University, Stanford, Calif. (hereafter Ruiz Papers). 
The organization's first president invoked the phrase "La union hace la fuerza" (unity is strength) to remind members about building unity among athletes, coaches, and spectators. The city's sports supervisor, Dudley Shumway, praised MAASC's members for "filling a big gap in the local Mexican community," and added, "I sincerely believe that it will be a powerful influence in uniting all the branches of sport in Southern California's Mexican community." ${ }^{26}$

The organizational structure included three executive board members (president, secretary, and treasurer), a small group of advisers, several standing committees, sport commissioners, and members who belonged to community sports clubs. The executive board appointed a commissioner for each sport to be in charge of the tournament schedule. The executive board managed the budget and enforced rules of sportsmanship according to the Amateur Athletic Union. The advisory board consisted of the LADPR's Municipal Sports Division supervisor, the Mexican consul of Los Angeles, and "professional Mexican business men, who were held in high esteem in the Mexican colony." ${ }^{27}$ The standing committees included the Olimpiada Mexicana (Mexican Olympic Games, held during Cinco de Mayo), Gymnasium Project, finance, and publicity. At the end of each season every commissioner filed a report on tournament results, the names of the winners and participants, and a list of suggestions for improvement. To join, each member paid an annual fee of twenty-five cents and had to have "at least one parent of Latin American descent." 28 The purpose of the racial eligibility clause was to promote athletics among Latinos, but it was difficult to enforce and sometimes became controversial when athletes did not appear "Latino."

MAASC's executive board consisted of a mix of male athletes of Mexican descent. Some had been born in Los Angeles, grown up playing in the city's playgrounds, completed their high school and college degrees, and become professionals and civic leaders. These included Juan Acevedo, Ralph Romero, Juan Alonso, and Ray Sánchez. Others, like José Arteaga, Pedro Despart, Roberto

26. La Opinión, Nov. 27, 1933, p. 4.

27. Ibid. The Mexican American professionals included Manuel Ruiz, Jr., attorney; Peter Salas, president of the Mexican Chamber of Commerce; Dr. Reynaldo Carreon, president of the Beneficencia Mexicana; Dr. José Díaz, dentist; and Mauricio Calderón, music store owner.

28. La Opinión, Nov. 27, 1932, p. 4. 
Ortiz, Arturo Flores, and Francisco Costello, were born in Mexico and arrived in the Los Angeles area as youths with every intention of playing their favorite sport in México de afuera.

Acevedo was the most active member and prime mover behind MAASC, acting as secretary between 1933 and 1939. In the early 1930s Acevedo founded the Club Deportivo Atenas and competed in the Junior Olympics, cross-country races, and marathons. Acevedo organized the annual track-and-field events for the Olimpiada Mexicana. In 1939 he joined the cross-country team at University of California, Los Angeles (UCLA) on an athletic scholarship. After returning from military service, Acevedo took a job as a social worker and soon joined the 1947 campaign to elect Edward Roybal to the Los Angeles City Council. Acevedo gained important leadership and organizational skills with MAASC that later extended to the Mexican American Movement (MAM), Mexican American Political Association (MAPA), and the California Youth Authority (CYU) ${ }^{29}$ Ralph Romero attended Polytechnic High School and played baseball and basketball; after graduation in 1923 he worked for the city public works department. During the Olympics, Romero joined MAASC as the representative of the Hazard Latins sports club, for which he served as treasurer and president in 1934 while he attended law school at the University of Southern California. Ray Sánchez had been a star basketball player in high school and joined MAASC as the basketball commissioner. In 1936 he was appointed to lead a Mexican American political club in support of Franklin D. Roosevelt's re-election campaign and named his basketball team "On with Roosevelt."

A chief proponent of Mexican nationalism in México de afuera, Arteaga coached and managed the Club Deportivo Los Angeles, which fielded several basketball teams, including Bohemia, L.A. Mexicans, and Arriola athletic clubs. Arteaga joined MAASC in order to organize an amateur basketball league tournament and travel to Mexico to compete in exhibition games. In 1932 Arteaga wrote an editorial titled "The momentum of sports in México de

29. Between 1933 and 1936 Juan Acevedo held the city's three-mile record (17 minutes, 20 seconds). La Opinión, Nov. 5, 1935, p. 4; ibid., Aug. 2, 1936, p. 4. On Acevedo's political biography, see Kaye Lynn Briegel, "The History of Political Organizations among Mexican-Americans in Los Angeles since the Second World War" (Ph.D. dissertation, University of Southern California, 1967), 50-51.

30. La Opinión, Jan. 27, 1936, p. 4. 
afuera" in which he expressed a commitment "to help President Rodriguez develop sports in Mexico." He reasoned that, "by playing [exhibition] matches in border towns, it will inspire and stimulate our [Mexican] brothers to take up sports." Coach Arteaga also reported on basketball tournaments and amateur athletes for La Opinión. Arteaga warned readers about unscrupulous sports promoters who intended to "make money from our athletes by paying them misery wages and dropping them when they could no longer profit from them." He cited an incident in which a promoter had defrauded members of the Atlético México club with the promise of financing their exhibition trip to Mexico City. ${ }^{31}$

Pedro Despart was elected MAASC president in 1939, and within a few months he diversified its sports offerings with tennis, swimming, football, wrestling, and amateur boxing. Like Arteaga, Despart forged close ties with Mexico's sports federations by cosponsoring exhibitions and hosting visiting athletes. Despart was a sport enthusiast who had received honors for high academic marks and track-and-field records at Lincoln High School. After graduation, Despart received a baseball scholarship at Arizona State University. Upon returning to Los Angeles, he helped MAASC organize fund-raising events, but, after a confrontation with some MAASC leaders, he left to organize a rival athletic organization called the Mexican Athletic Union (MAU). ${ }^{32}$ Years later Despart ran an unsuccessful campaign for a seat in the California State Assembly. ${ }^{33}$

MAASC promoted various types of amateur sports, beginning with track-and-field and basketball and later swimming, tennis, football, boxing, and softball. During its early years MAASC set forth an ambitious agenda to appoint commissioners and organize leagues for each sport, secure playing fields for practices and tournaments, and instruct athletes on the rules of "good sportsmanship." By 1933 MAASC claimed 115 athletic clubs, 38 baseball teams with over 500 total participants, 66 basketball teams

31. Ibid., Dec. 29, 1932, p. 4; ibid., Oct. 30, 1932, p. 4; ibid., Oct. 28, 1934, p. 5.

32. Ibid., Nov. 30, 1936, p. 4.

33. On Pedro Despart's brief political career, see Kenneth Burt, The Search for a Civic Voice: California Latino Politics (Claremont, Calif., 2007), 16. Francisco Costello was another member of MAASC's executive board who also wrote a weekly sports column for La Opinión. Costello played a key role in MAASC's publicity efforts by reporting on their activities and monthly meetings. La Opinión, Jan. 7, 1937, p. 4. 
in leagues with over 450 participants, 16 softball teams with 225 players, and 5 track-and-field events with 425 participants and attracting over 1,600 spectators. ${ }^{34}$ Some of these clubs reflected both México de afuera and Mexican American ideologies. They included Club Oh Señor, Club Atenas, Club Iris, Club Bohemia, Club Atlético Olimpia, Club Atlético México, Club Monte Carlo, Club Bolívar, Club 'On with Roosevelt', Club Arriola, Club Minerva, Club Benito Juárez, Club Aguilas Reales, Club Evergreen Knights, Club Alma Joven, Club Aztecas, and Club Moctezuma.

Men held all leadership positions within MAASC. A combination of Mexican masculinities, from traditional to modern migrant forms, contributed to the group's male orientation and promotion of "manly" sports. ${ }^{35}$ Women were allowed to participate in traditional feminine sports like tennis, softball, and gymnastics. Dudley Shumway, head of the Municipal Sports Division, emphasized the sports' masculine character: "This is the moment in which we should lend our support to all Mexican amateurs who have great abilities to convert themselves into great athletes. . . athletics has proven to be the best means in which to make good male citizens." ${ }^{36}$ MAASC's president used similar gendered language: "Instructing athletes to be truly sportsmanlike, competing honorably and with fair play, and being truthful noblemen when they win or lose." ${ }^{37}$ Since the late nineteenth century sports had been a social institution through which "masculine hegemony" was constructed and reconstructed by linking specific sports with male aggression and by allowing men to govern sports organizations. ${ }^{38}$

MAASC's first athletic event was a track-and-field meet at Evergreen Playground, held in conjunction with Cinco de Mayo festivities. The event was called Olimpiada Mexicana for its resemblance to the Olympic Games. Shumway praised the 250 athletes

34. Ibid., May 5, 1933, p. 4.

35. For a discussion of multiple Mexican masculinities negotiated by first- and second-generation Mexican migrants, see Robert Courtney Smith, Mexican New York: Transnational Lives of New Immigrants (Berkeley, 2006), 94-146.

36. La Opinión, Nov. 20, 1932, p. 4. Originally in English and translated into Spanish by Rafael Ybarra, sports columnist for La Opinión.

37. La Opinión, March 26, 1933, p. 4.

38. Michael Kimmel, Manhood in America: A Cultural History (New York, 1996), 137-141; David Whitson, "Sport in the Social Construction of Masculinity," in Michael A. Messner and Donald F. Sabo, eds., Sport, Men, and the Gender Order: Critical Feminist Perspectives (Champaign, Ill., 1990), 19-29. 
and 6,000 spectators for their participation and "for lifting the spirits of the Mexican Athletic Association and their magnum opus." La Opinión sportswriters credited MAASC officials for "their unselfish undertaking in trying to unite the Mexican colony" and remarked how the "chicanitos" of Club Trojan won first place in a majority of races. ${ }^{39}$

Olimpiada Mexicana became a larger event the following year (1934) because city mayor Frank Shaw helped secure the Los Angeles Memorial Coliseum, the largest sports venue in the city. This event featured a polo game, soccer match, music, awards ceremony, dancing, and the coronation of the Olimpiada Mexicana queen. MAASC organizers recruited over forty athletic clubs from across Southern California (principally Orange County and San Fernando Valley), over 4,000 athletes (between the ages of fifteen and twenty-two), and over 20,000 spectators. MAASC invited special guests, including Hollywood celebrities, boxing champions, the mayor and police chief of Los Angeles, and the California governor. One MAASC organizer reminded La Opinión readers to wear their best Mexican costumes and arrive with "proper enthusiasm so that we can demonstrate to the [Anglo] American audience that our [Mexican] colony will not only be the largest population locally, but the most powerful in culture, athletics, and discipline." ${ }^{40}$ MAASC organizers sought to use sport participation to present a positive image of a Mexican population that was still considered a "racial problem" during the mid-1930s.

Another MAASC objective was to showcase the athletic talents of its youth so that they might earn athletic scholarships to colleges or universities. In fact, Bert Corona attended the University of Southern California on a basketball scholarship. "On certain game trips outside of El Paso, we encountered quite a bit of harassment," recalled Corona; "we got booed and called all kinds of dirty names. These places where Mexicans weren't liked hated seeing their home teams beaten by Mexican athletes. ${ }^{21}$ Acevedo was an example of a MAASC athlete who earned a college scholarship to UCLA. One community college coach admitted that

39. La Opinión, May 9, 1933, p. 4; ibid., May 4, 1933, p. 4; ibid., May 9, 1933, p. 4; ibid., March 27, 1934, p. 4. Several La Opinión sports articles referred to young athletes of Mexican descent as "chicanos" or "chicanitos."

40. Ibid., May 6, 1934, p. 7; ibid., May 5, 1935, p. 9.

41. García, Memories of Chicano History, 59. 
"Those Mexican boys are bringing much strength into the current sport movement, and in the long run, will gain more honors than those [white] American boys in the universities, colleges, and high schools of Los Angeles." ${ }^{42}$

During a 1937 MAASC basketball tournament the winning team was invited to play an exhibition game against a local college team. Centinelas Athletic Club was considered one of "the most powerful Mexican aggregations ever gathered in Southern California." After Centinelas roundly defeated Occidental College's Tigers by fourteen points, the Los Angeles Times took notice of the top Centinelas player, José Placencia, who "was selected to play on the Mexican Olympic basketball team which went to Berlin [in 1936]" and became the 1942 Amateur Athletic Union's basketball top scorer. "Maybe representatives from the University, who are always looking for new material, will finally take notice of our athletes," declared sportswriter Francisco Costello. ${ }^{43}$ Placencia's athletic achievement generated publicity for the MAASC basketball tournament and showed the general public that Mexican American athletes were capable of competing and winning at a collegiate level.

Even though MAASC leaders insisted on "good sportsmanship," the competitive nature of sports made this policy difficult to enforce during matches. Still, only on rare occasions did matches erupt into fights. During the 1934 basketball season, controversy arose when Club Minerva's coach, Benito Montoya, threatened to leave the tournament because of false accusations. When Club Iris was about to lose the match, its members accused Club Minerva of fielding a "negro player" in violation of MAASC rules allowing only players of Latin American descent. Montoya defended Kenny Washington's ethnic identity, claiming that he was the son of a black father and a Mexican mother, had grown up in a Mexican neighborhood, and spoke Spanish fluently. Montoya complained that "Club Minerva players forfeited the game and ridiculed Washington, who felt embarrassed as he walked off the court in silence." ${ }^{44}$ MAASC leaders mishandled the incident by neglecting to take disciplinary action against Club Iris's "bad sportsmanship." This conflict revealed the contested meaning of mexicanidad,

42. La Opinión, May 4, 1933, p. 5.

43. Los Angeles Times, Feb. 8 1937, p. A11; ibid., March 2, 1942, p. 18; La Opinión, April 16, 1934, p. 7.

44. Ibid., Dec. 30, 1933, p. 7. 
which has been narrowly defined as a mixture of indigenous and European heritage, ignoring the African element in the Mexican diaspora. $^{45}$

\section{Confederación Deportiva Mexicana}

International sporting exchanges between Mexico and the United States are not a recent phenomenon; since the 1920s both countries have competed in the Olympic Games, FIFA (Fédération Internationale de Football Association) soccer tournaments, and "goodwill" exhibition games. ${ }^{46}$ By the 1930 s Mexico's postrevolutionary government sought closer ties with México de afuera through the country's new sports federation.

Mexico developed its national sports program much later than the United States, in January 1933 when President Abelardo Rodríguez established the nation's first sports federation, Confederación Deportiva Mexicana (CDM), with the chief aim of promoting physical exercise, discipline, and nationalism. ${ }^{47}$ President Rodríguez appointed Lamberto Alvarez Gayou as director of physical education in charge of making Mexico a "sports-minded nation." A former champion gymnast, Gayou had studied physical education at UCLA and after graduation became a sportswriter and sports promoter on both sides of the U.S.-Mexican border. ${ }^{48}$ "Mexico realizes that its athletic future lies with its youth," wrote Gayou, "so it is on youth that it is concentrating its intensive campaign to develop physically and morally the Mexican people and enhance the prestige of the nation." 49 His first action was to introduce a junior pentathlon program, modeled after the Los Angeles junior pentathlon. A year later Mayor Shaw of Los Angeles praised President Rodríguez for hosting the first International

45. Martha Menchaca, Recovering History, Constructing Race: The Indian, Black, and White Roots of Mexican Americans (Austin, Tex., 2001), 2-5.

46. Rudolph Muller Lopez, "History of Physical Education and Sports in Mexico" (M.A. thesis, Claremont Graduate School, 1953), 87-132; Joseph Arbena, "Sport, Development, and Mexican Nationalism, 1920-1970," Journal of Sport History, 18 (1991), 350-364.

47. On the Confederación Deportiva Mexicana (CDM), see Keith Brewster, "Patriotic Pastimes: The Role of Sport in Post-Revolutionary Mexico," International Journal of the History of Sport, 22 (2005), 145.

48. Los Angeles Times, Jan. 22, 1933, p. E3; San Diego Sun, April 19, 1933, p. C5.

49. Lamberto Alvarez Gayou, "A National Sports Program," Journal of Health and Physical Education, 14 (1943), 8. 
Junior Pentathlon meet: "We are pleased to know that your government has adopted this program as a regular part of the curriculum in your public schools. ${ }^{" 50}$ Despite the rising interest in sports, according to Gayou, "we lack trained physical educators and coaches. ... There are no sports clubs in Mexico like the Los Angeles Athletic clubs." Using the Amateur Athletic Union as a model, Gayou pushed for the creation of CDM, a national governing body to oversee organized sports and coordinate national athletic competitions. ${ }^{51}$

Like Gayou and Rodríguez, President Lázaro Cárdenas understood that Mexico could learn much from American sports, so he sought to strengthen athletic ties with México de afuera. During the mid-1930s Cárdenas expanded physical education, parks, and sports programs as part of his populist and nationalist agenda. ${ }^{52}$ On March 17, 1937, Cárdenas sent two CDM athletes, Jose de Anda and Fernando Campo, to meet with MAASC president Ralph Romero to discuss ways "to tighten our sporting relations." The visitors received a special dinner, hosted by MAASC and the Los Angeles Mexican Consul. MAASC athletes were invited to compete in the Mexico City trials for the 1938 Central American Games. De Anda explained how impressed they were with MAASC athletes: "We have a great desire to include the best athletes living in Southern California to compete for a spot in the [Mexican] national team for the Central American Games in Panama." Two months later CDM's president, Gustavo Arévalo Vega, invited MAASC leaders to become partners with his sports federation. Vega emphasized that "It is our fervent desire to be united with our brothers who live outside of our country." CDM offered to defray a portion of transportation costs for MAASC athletes who wished to participate in the Mexico City trials. Acevedo led the team of eight track-and-field athletes to Mexico City; out of the three who joined Mexico's national team, Francisco López won first prize at the Central American Games. ${ }^{53}$ After agreeing to work with CDM,

50. Los Angeles Times, Aug. 6, 1933, p. D4; Frank Shaw to Abelardo Rodríguez, July 14, 1934, Rodriguez Papers, ALR 332.3/187.1, Archivo General.

51. Los Angeles Times, Jan. 22, 1933, p. E3; Gayou, "A National Sports Program," 8.

52. Mary Kay Vaughan, Cultural Politics in Revolution: Teachers, Peasants, and Schools in Mexico, 1930-1940 (Tucson, Ariz., 1997).

53. La Opinión, March 21, 1937, p. 5; ibid., March 17, 1937, p. 7; ibid., May 9, 1937, p. 7; ibid., Dec. 10 1937, p. 7. 
MAASC appointed Guillermo Eddy as its official CDM representative in Mexico City. ${ }^{54}$

After forming a bi-national partnership, MAASC and CDM co-sponsored a series of exhibition basketball games in Mexico. In the early 1900s the Young Men's Christian Association (YMCA) had introduced basketball to Mexico, and by 1934, according to one physical education director, the game had become "the most popular sport with a total of 40,000 players." Mexico made a strong showing at the 1936 Olympics in Berlin when its basketball team, which included Mexican Americans, won a bronze medal. To practice for the Olympic Games, CDM and MAASC co-sponsored the Centinelas Athletic Club to travel to Mexico for ten basketball exhibition matches. Coached by MAASC advisory board member Dr. Angel Antonio Loyo, the Centinelas team won seven games and lost two against a Chihuahua team. The Mexican Olympic Committee was so impressed by the visiting players that it asked Loyo if the team's top player, José Placencia, could join Mexico's Olympic basketball team. The Centinelas exhibition tour, according to Loyo, demonstrated that "[MAASC] has extended its jurisdiction to the other side of the border, making possible that our boys from our jurisdiction get recognized for their worth." ${ }^{55}$ Gaining international recognition for their athletic talent was significant, given prevalent racial beliefs in the United States about the supposed mental and physical inferiority of Mexican immigrants. ${ }^{56}$

To strengthen their athletic partnership, MAASC leaders also invited CDM athletes to compete in their 1938 Olimpiada Mexicana event at the Los Angeles Coliseum. The fifteen visiting athletes from Mexico surprised local observers by winning first place in eleven competitions. Described as "the crack squad of athletes from Mexico" by the Los Angeles Times, "the boys from Mexico were the pick of the southern republic. Some of them won championships

54. The MAASC letterhead included the following inscription: "Miembro de la Confederación Deportiva Mexicana." Letterhead, Jan. 31, 1940, folder 14, box 4, MO295, Ruiz Papers.

55. Oscar Castillon, "Physical Education in Mexico," Journal of Health and Physical Education, 5 (May 1934), 13; Theodore Allan Ediger, "Mexico, the Land of Sports," Pan American Magazine, 3 (1930), 198-208; La Opinión, March 16, 1936, p. 7.

56. Some academics claimed that Mexican children were physically inferior and showed little interest in participating in sports; see Jorge Iber, "Mexican Americans of South Texas Football: The Athletic and Coaching Careers of E. C. Lerma and Bobby Cavazos, 1932-1965," Southwestern Historical Quarterly, 55 (2002), 622-623. 
at the Central American Latin Olympic Games in Panama last year." The following year MAASC recruited "the cream of the crop" from Los Angeles City College to compete against Mexico's top athletes. ${ }^{57}$ Each year the number of visiting athletes increased, attracting more spectators to the Los Angeles Coliseum eager to watch this international competition, but the gate receipts were not enough to offset expenses.

State boxing regulations and financial problems threatened to cancel athletic events. When both groups proposed an amateur boxing tournament called the "Mexican Golden Gloves" in Mexico City, the California State Athletic Commission (CSAC), the agency that regulated boxing, denied their request. MAASC leaders appealed the decision, arguing that this tournament would improve "goodwill relations" between both countries. After receiving approval, MAASC officials decided to stage the boxing event at the Olympic Auditorium because "it costs more money to send our boys than to bring your athletes here to Los Angeles." 58 MAASC's boxing commissioner Midget Martinez proposed to President Cárdenas that, if CDM paid the Mexican athletes for travel to Tijuana, MAASC would cover the remaining cost to Los Angeles. Cárdenas approved Martinez's request, stating, "I have already given instructions to the Confederación Deportiva Mexicana so that it takes care of this request." ${ }^{59}$ The first tournament was considered a great success, with Mexico's boxers winning all eight divisional titles. To improve MAASC's losing record, Martinez organized an elimination tournament, with coaching help from prizefighter Bert Colima. During the 1920s Colima had been a big name in Southern California, selling out boxing arenas. Although he was born in Whittier, California, as Epifanio Romero, he later changed his name to that of his mother's home town of Colima, Mexico. In 1928 he won the Mexican middleweight title in Mexico City and was lavished with praise by local fans and sports writers. With Colima's help, MAASC boxers, Gregorio Escalona and Tony

57. La Opinión, April 28, 1937, p. 7; Los Angeles Times, April 29, 1938, p. A12; ibid., April 30, 1939, p. A14; La Opinión, March 13, 1941, p. 7.

58. Ibid., July 3, 1939, p. 7; ibid., July 11, 1939, p. 7.

59. Lázaro Cárdenas to Mexican Athletic Association of Southern California, July 14, 1939, Lázaro Cárdenas Papers, LC 532/94, Archivo General. 
Contreras, won two out of seven matches. ${ }^{60}$ Building transnational ties with the Mexican government and local ties with sports promoters and homegrown organizations not only allowed MAASC to support its athletes but also infused leaders with more confidence to challenge the city's recreation department.

\section{The Los Angeles Department of Playground and Recreation}

Early Americanization efforts in the city's public heath programs and recreational playgrounds had treated Mexicans as capable of assimilation but also as racialized subjects in need of guidance and direction. The LADPR resembled the Los Angeles Bureau of Music in its "racial paternalistic" approaches toward immigrant and racial minority residents. ${ }^{61}$ When the city's recreation department announced the formation of MAASC, there was some suspicion, if not mistrust, about the city's intentions. LADPR Superintendent George Hjelte proclaimed during a keynote speech to the Friday Morning Club that "supervised recreation centers can be a determining factor in promoting good Americanism." 62 "Supervised play" was a common catch phrase used by municipal recreation officials to cloak their Americanization efforts. Dudley Shumway, LADPR's municipal sports division supervisor, reassured La Opinión readers that "The importance of this relationship is that the municipal government does not intend precisely to 'Americanize' its affiliate [Mexican] groups but only to apportion the necessary measures so they can develop their athletic faculties." ${ }^{63}$

60. Los Angeles Times, July 31, 1939, p. 23. According to a sports columnist, "In Mexico [Bert] Colima was lionized. He was guest of President Calles. Bulls were killed in the bull ring in his honor. Newspaper lavished their space on him." In ibid., May 30, 1926, p. A5; ibid., Nov. 21, 1939, p. A13.

61. Natalia Molina, Fit to be Citizens? Public Health and Race in Los Angeles, 18791939 (Berkeley, 2006), 75-115; Marlou Belyea, "The Joy Ride and the Silver Screen: Commercial Leisure, Delinquency and Play Reform in Los Angeles, 1900-1980" (Ph.D. dissertation, Boston University, 1980), 47-49; Anthony Macías, "Bringing Music to the People: Race, Urban Culture, and Municipal Politics in Postwar Los Angeles," American Quarterly, 56 (2004), 693-717.

62. Los Angeles Times, Jan. 5, 1935, p. A6.

63. La Opinión, Nov. 20, 1932, p. 7. Originally spoken in English and translated into Spanish by La Opinión. 
Three years later, however, the relationship between MAASC members and Shumway began to break down. On September 21, 1935, LADPR sponsored an exhibition football game between National University of Mexico and Occidental College at the Los Angeles Coliseum. To earn one-quarter of total ticket sales, MAASC agreed to sell tickets, decorate the stadium with Mexican flags, broadcast the game in Spanish, and sit in the "Mexican section to cheer for their football players from Mexico." MAASC acquiesced to this segregated seating arrangement but expressed disappointment with the portrayal in the Los Angeles Times of Mexico's football players as "Mexican jumping beans" and "Latin Leviathans." Using a series of racial stereotypes for Mexican athletes, the newspaper reported that "a band of Mexican footballers aren't much to look at. They're light. They're small. But like chili con carne, they have a lot of pepper." ${ }^{64}$ To counter the negative press coverage, Mexican fans hoped for an underdog victory against the more powerful Occidental football squad, but, despite over 6,000 Mexican spectators cheering for their compatriots, the Mexican team lost by 21 points. ${ }^{65}$

Losing the football game was disappointing, but even more upsetting was not receiving a share of the profits. When MAASC president Juan Alonso inquired about the missing funds, Shumway told him there was no money left, due to a $\$ 150$ debt. "We believe this is a great injustice," Alonso angrily complained to the press, "because the members of [MAASC] spent at least $\$ 200$ to promote this event." Shumway denied that he had promised one-quarter of total ticket sales to MAASC. Soon thereafter Alonso resigned in protest and urged MAASC members to sever ties with Shumway. ${ }^{66}$ After Alonso's resignation, several sports clubs also declared their independence from the city because of Shumway's disrespect for MAASC.

Momentum to split from the city grew the following year when Shumway once again exerted his authority over MAASC leadership. MAASC's basketball commissioner Armando González

64. Ibid., Aug. 19, 1935, p. 7; Los Angeles Times, Sept. 20, 1935, p. A11; ibid., Sept. 21, 1935, p. 7. On the print media's racialization of Latino tennis players, see José M. Alamillo, "Richard 'Pancho' Gonzalez, Race, and the Print Media in Postwar Tennis America," International Journal of the History of Sports, 26 (2009), 947-965.

65. La Opinión, Nov. 17, 1935, p. 7.

66. Ibid., March 24, 1936, p. 7; ibid., Dec. 21, 1935, p. 5. 
complained that Shumway had arbitrarily disqualified a basketball team because it failed to turn in an eligibility list before the deadline. According to González, "[Shumway] undoubtedly thinks that they can expel any team that does not abide by the rules, but the only one that can do that is me, as head commissioner of the [MAASC] basketball league." During a heated confrontation with Shumway, González accused the city recreation department of "trying to command the membership of the Association with an iron hand." The final straw came when Shumway financed the travels of his favorite basketball team (Centinelas) for exhibition games in Mexico, even though they had lost the basketball tournament. This move angered the winning team, the Club Deportivo Mexico, which urged the new MAASC president, Roberto Ortiz, to take action against Shumway and to "work hard to separate from the Department of Recreation and Playgrounds."

During a "heated and sensational" meeting on March 28, 1936, MAASC members voted to oust Shumway from the advisory board and to move their meeting location from the city hall to Evergreen Playground in East Los Angeles. "This move," declared Ortiz, "was one step in breaking definitively from Mr. Dudley Shumway who has been governing the destinies of our Association since its founding." Ortiz clarified that the battle was against Shumway, but he also held the city recreation department responsible for not taking any disciplinary action. "Now that the Association is free," La Opinión columnist Francisco Costello reminded its members that "We need to prove to Shumway that we are very capable of doing a good job of bringing sports to the Mexican youth of Los Angeles." Costello urged former members (Juan Alonso, Ray Sánchez, Arturo Flores, and José Arteaga) to return to MAASC to prove to Shumway that they could organize their own events. Juan Acevedo attributed the success of Olimpiada Mexicana to the organization's newfound independence. "After the Association was freed from the yoke of the Department of Recreation," Acevedo observed, "we have come to see the spirit and willingness of the various parts of the Association working together much better." 68 The Olimpiada Mexicana event took on a greater significance since

67. Ibid., March 23, 1936, p. 7; ibid., March 8, 1936, p. 6; ibid., Jan. 25, 1936, p. 7.

68. Ibid., March 28, 1936, p. 7; ibid., April 12, 1936, p. 7; ibid., March 30, 1936, p. 7; ibid., May 10, 1936, p. 7. 
it allowed MAASC members to prove to themselves and their peers that they were capable of working together and organizing a successful large-scale sporting event.

Several months later Shumway retaliated by revoking MAASC's use permit for the Evergreen Playground and Recreation Center's gym that hosted the annual basketball tournament. "Once again Shumway has demonstrated his prejudice against the Association for having liberated itself from the yoke of his department," wrote Francisco Costello in his weekly column. This move created logistical and financial problems, forcing the MAASC to postpone the tournament. A basketball player complained about Shumway to $L a$ Opinión, accusing him of "doing destructive work among the ranks of the Association and by denying us permission to practice in the gymnasium." Then, to add insult to injury, Shumway threatened to retrieve the city trophy awarded to the winning team of the MAASC basketball tournament. "Is it really necessary to be prejudiced against the MAASC?" asked one La Opinión sports columnist; "It looks really bad for a high-level city official to try to take away a trophy that his own department donated." Shumway's retribution served as a wake-up call for MAASC to become more financially independent. "Shumway has tried to harm us by closing the gates to the city's playgrounds," declared MAASC basketball commissioner Ray Sánchez: "Now is the time for all [MAASC] members to be extremely united to show Mr. Shumway that Mexicanos know how to work well together and can succeed financially." ${ }^{69}$ Sánchez enlisted the help of the Mexican consul of Los Angeles, who then complained to Mayor Shaw, forcing Shumway to back away from his threat.

\section{Forging an athletic movement}

After MAASC broke its ties with the city's recreation department in December 1936, the group faced major challenges in organizing athletic events for the Mexican population, but it still managed to forge an "athletic movement" by using local and transnational sporting networks. ${ }^{70}$ The first problem was finding a location to hold its monthly meetings. Since its inception, MAASC had worked closely with the Mexican consuls of Los Angeles, who

69. Ibid., Oct. 4, 1936, p. 7; ibid., Dec. 20, 1936, p. 7; ibid., Dec. 4, 1936, p. 7.

70. Ibid., Jan. 25, 1937, p. 7. 
served on their advisory board, made guest appearances at athletic events, and granted permission to hold meetings at the consulate office. ${ }^{71}$ In addition, the Mexican consul helped sponsor MAASC athletes to compete in exhibition matches in Mexico. Los Angeles consul Joaquín Terrazas explained that, "if we want our sons to grow up wholesome and strong, we should make sports part of their activities . . . and [let them] compete in athletic tournaments." The Mexican consul helped MAASC organize the Olimpiada Mexicana on May 5, 1936, at the Los Angeles Coliseum. The consul negotiated a low stadium price and awarded trophies to the winners. ${ }^{72}$ The newly appointed Mexican consul of Los Angeles, Renato Cantú Lara, donated the "Cantú Lara Trophy" for the winner of the 10,000-meter race. He also sent a special bulletin to Comisiones Honoríficas (honorary commissions) throughout Southern California, instructing them to send athletes to attend "the [MAASC] sport festival, which will be colorful and overflowing with enthusiasm."73

To make the Olimpiada Mexicana a success, even without the city's help, Ralph Romero, Pedro Despart, and Juan Acevedo (MAASC leaders from 1936 and 1942) forged stronger ties with the Mexican consul, Hollywood celebrities, Spanish-language print media, sports promoters, and Mexican American organizations. Acevedo resolved the problem of late registrations by publishing the form with rules and regulations in La Opinión sports pages. Acevedo also solicited three new trophies for the winners, one donated by $L a$ Opinión's owner, Ignacio Lozano, one by the Mexican consul, and one by Mayor Fletcher Bowron. In addition, Acevedo invited Hollywood actor Leo Carrillo to serve as the master of ceremonies. Carillo's debut was a huge success, attracting over 40,000 attendees and much praise from athletes. ${ }^{74}$ A year later MAASC invited athletes

71. Historians have documented the Mexican consul's role in México de afuera, which included sponsoring patriotic celebrations, establishing Spanish-language libraries, forming community organizations and labor unions, and assisting repatriation efforts during the Great Depression, but they have largely ignored their role in promoting athletics. See Sánchez, Becoming Mexican American; Balderrama, In Defense of La Raza; and González, Mexican Consuls and Labor Organizing.

72. La Opinión, Aug. 9, 1935, p. 7; ibid., May 2, 1936. The Mexican consul persuaded Ralph Chick, head of the Los Angeles Coliseum, to allow MAASC to use the sports facility for a low price.

73. San Antonio [Tex.] La Prensa, April 9, 1938, p. 7.

74. Ibid., April 25, 1937, p. 7. 
from Mexico City, Baja California, and Arizona to compete in the largest sport festival so far. The Los Angeles Times praised the event as "one of the gayest of the Mexican celebrations, the holiday witnessed a gala fiesta and track meet at Memorial Coliseum . . . one of the largest and most colorful programs ever presented by the Mexican colony." In a dramatic showing of "good neighbor" relations, the Mexican consul hoisted the U.S. flag while Mayor Bowron raised the Mexican flag. Bowron declared, "It is an inspiring spectacle to witness this celebration of the people of a nation which, like our own, loves peace, liberty, and independence. We hope that Mexico and the United States may be in peace as long as their flags shall wave, and may they wave forever." ${ }^{75}$

Government officials were not the only ones to invoke the official Good Neighbor Policy; MAASC leaders also used the rhetoric of inter-American cooperation to gain support for their athletic events. On September 4, 1939, MAASC teamed up with boxing promoter Henry von Stumme to organize a Labor Day Sports Fiesta at his outdoor arena in the San Fernando Valley. The event featured eight amateur bouts, a women's softball game, a baseball game, and the selection of a Reina Mexicana del Deporte (Mexican sports queen), followed by a jitterbug dance contest. ${ }^{76}$ According to MAASC, the event's purpose was to create "A fund which will make possible the goodwill exchange of athletes of Latin American descent with those of the neighboring [Mexico] republic." Besides raising money to send a "Mexican-American ring team" to Mexico City for an international boxing competition, the boxing show featured "Latin American ring greats" Bert Colima, Joe Rivers, Baby Arizmendi, and Joey Silva, who "mingle[d] with outstanding prospects for the future." ${ }^{\prime 7}$ As historian Monroy has pointed out, "The Mexican boxers quickly became an important presence in the arenas of California and provided a central means by which men's ethnic consciousness was formed."78

When MAASC leaders encountered problems securing tennis courts and trophies for their tennis tournament, they asked Hollywood Mexican actor Gilbert Roland for assistance. Roland responded generously by donating a singles trophy for the male

75. Los Angeles Times, May 8, 1939, p. 3.

76. La Opinión, Sept. 4, 1939, p. 7.

77. Los Angeles Times, July 31, 1939, p. 23; ibid., Aug. 27, 1939, p. A9.

78. Monroy, Rebirth, 56-57. 
winner and offering to use his celebrity status to generate publicity. He also helped MAASC to gain access to the much larger tennis courts at Griffith Park. Roland himself was an elegant tennis player who agreed to an exhibition match against a visiting Mexican Davis Cup team member. ${ }^{79}$ Not until 1940 were Mexican women allowed to compete in the MAASC tennis tournament. When female players became part of the tournament, La Opinión wrote that "The spectators were surprised to see such a young pretty señorita, Margarita Gómez, defeat Ana Mellon 2-6, 6-2, 6-3 to clinch the women's singles title." ${ }^{80}$ La Opinión sports writers used gendered language to describe the physical attributes of female athletes rather than their athletic skills.

After MAASC cut its ties with the city recreation department, the association was forced to pay higher fees for private sport facilities and high school gyms where its programs took place. In February 1937, therefore, MAASC embarked on its most ambitious fundraising project-to build its own gymnasium. A special gymnasium project committee was formed to raise money and put on a special banquet to honor the association's biggest supporters. ${ }^{81}$ The first step was to consult with attorney and advisory board member Manuel Ruiz, Jr., about seeking non-profit status. Using gendered language, Ruiz drafted the application outlining its main purpose: "to promote the physical, cultural, social intercourse and recreation of its members and to encourage all proper and manly sports and pastimes." Once MAASC acquired non-profit status, Ruiz proposed that the organization request the Los Angeles Board of Education to grant an exemption from paying service fees for high school gyms. In a letter to the school board, Ruiz explained that MAASC had "for some years engaged in character-building activities for young Mexican boys in athletics. ... [which] has directly

79. La Opinión, Oct. 1, 1939, p. 7; ibid., Sept. 30, 1939, p. 7. Out of the thirty-six competitors, Fernando Isais won the Roland Trophy. Isais won four singles championships, including defeating the young up-and-coming tennis star, Richard "Pancho" Gonzalez, in the 1942 tournament. Isais was selected to compete in the 1941 Revolutionary Games in Mexico City, but, instead of pursuing a tennis career, Isais decided to compete professionally in horseshoe pitching contests, winning a total of six world championships. Ibid., Sept. 16, 1939, p. 7.

80. Ibid., Sept. 12, 1940, p. 4; ibid., Sept. 25, 1940, p. 7; emphasis added.

81. Ibid., Feb. 7, 1937, p. 7. Special invitees included Mexican Consul Renato Cantú Lara, Los Angeles mayor Frank Shaw, Los Angeles police chief James Davis, Los Angeles Coliseum director, Ralph Chick, and La Opinión sports editor, Pete Delgado. 
contributed to the partial solution of the juvenile delinquency problem." Ruiz requested that the school board rescind the charge of service fees for use of gymnasiums because it "has imposed such a hardship that the athletic schedule this year cannot be carried forward." A week later MAASC received a letter from Ruiz that the "Board has rescinded its action and has withdrawn the charge involved in the use of school gymnasiums." ${ }^{22}$

Despite this small victory, Arteaga was still frustrated by the lack of progress in building MAASC's own gymnasium. "The Association still does not have a suitable place to carry out its sports program," complained Arteaga, who blamed the city's recreation department for its lack of support and for contributing to the "pachuco problem." "At one time, [MAASC] had a remedy for the pachuco problem," he asserted in La Opinión, "but the selfishness of city employees with the power in their hands ruined a noble effort, and if they had given more support to them [MAASC athletes] there would not have existed a pachuco problem." 83 Most scholars have attributed the "pachuco" and "zoot suit" hysteria to wartime anxieties, Los Angeles police arrests, and newspaper stories, but none have considered how the discriminatory actions of municipal recreation officials may have also contributed to the youth rebellion. ${ }^{84}$

Amid these financial worries, a powerful struggle emerged within MAASC's leadership in which some board members tried to oust Pedro Despart. During a summer trip to Mexico City, Despart accused MAASC executive board members of holding elections in his absence; after protesting the results, he resigned and, along with Ray Sánchez, formed a rival organization, the Mexican Athletic Union (MAU). ${ }^{85}$ MAU held its first meeting at

82. "Gymnasium Proposal," June 1937, p. 1, folder 14, box 4, MO295, Ruiz Papers; emphasis added. Ruiz to Los Angeles Board of Education, Feb. 1, 1941, in ibid.; Ruiz to Ralph Romero, Feb. 7, 1941, in ibid.

83. La Opinión, Feb. 2, 1939, p. 5; ibid., June 27, 1943, p. 7.

84. "Pachuco" refers to Mexican American youths who developed their own subculture during the 1940s. Escobar, Race, Police, and the Making of a Political Identity; Eduardo Obregón Pagán, Murder at the Sleepy Lagoon: Zoot Suits, Race, and Riot in Wartime L.A. (Chapel Hill, N.C., 2003), 126-142; Luis Alvarez, The Power of the Zoot: Youth Culture and Resistance during World War II (Berkeley, 2008), passim.

85. La Opinión, Aug. 18, 1940, p. 7. The Mexican Athletic Union (MAU) lasted until December 1949, organizing annual tournaments in tennis, baseball, softball, bowling, and basketball. It also introduced the annual "Tortilla Bowl" football game at White Sox Park. Los Angeles Times, Jan. 5, 1941, p. A12. 
Downey Playground and even invited MAASC's foe, Dudley Shumway, to say a few words in support of MAU activities. With the exception of football, MAU competed with the MAASC in offering similar sports programs. This caused confusion among local athletes and Mexican government officials. In a sharply worded letter to both athletic organizations, Mexico's Director of Physical Education Ignacio Beteta advised the two organizations to put aside their differences and "unite their forces to work together for the improvement of sports among the Mexican youngsters who live outside of Mexico." ${ }^{86}$ Los Angeles vice consul Eduardo Zembrano convened a special meeting with both groups to resolve their differences but was met with little success. It took the arbitration skills of attorney Manuel Ruiz, Jr., to bring the two rivals together. After a lengthy meeting at Evergreen Playground, El Espectador reported that "It was decided in this meeting that both athletic organizations will cooperate to the fullest extent with each others' activities and not encourage friction between both organizations which will disrupt the relationship now established." ${ }^{\text {77 }}$ Both organizations decided to coordinate a master schedule and offer separate sports programs; MAASC coordinated track-and-field, tennis, adult basketball, and swimming, whereas MAU organized football, women's softball, amateur boxing, and junior basketball.

After helping to resolve the conflict with its rival athletic organization, MAASC worked more closely with Ruiz to reestablish relations with the city recreation department to combat juvenile delinquency. ${ }^{88}$ Ruiz had been the Manual Arts High School's valedictorian, debate team captain, and a track star who received a scholarship to attend the University of Southern California. After college graduation, he opened a law practice and offered legal

86. La Opinión, Sept. 29, 1940, p. 4; ibid., March 30, 1941, p. 4.

87. El Espectador, Aug. 13, 1941, p. 1. Based in Pomona, California, this weekly bilingual newspaper was published and edited by Ignacio Lopez. See Mario García, Mexican Americans: Leadership, Ideology and Identity (New Haven, Conn., 1989), 84-112.

88. Most writings on Ruiz have focused on his organizational work with the Coordinating Council for Latin American Youth (CCLAY), Cultura Pan-Americana, Inc., and the Sleepy Lagoon Defense Committee, but they have neglected his early involvement in MAASC. See Mario García, "Americans All: The Mexican American Generation and the Politics of Wartime Los Angeles, 1941-45," Social Science Quarterly, 65 (1984), 278-289; Escobar, Race, Police, and the Making of a Political Identity, 203-226; and Obregón Pagán, Murder at the Sleepy Lagoon, 30-36. 
advice to several Mexican American organizations. ${ }^{89}$ As a former high school athlete, Ruiz strongly supported the use of sports to combat juvenile delinquency among Mexican American youth. He understood that "delinquency" was not a biological or cultural attribute associated with Mexican American youth, but a product of racism, economic factors, and social marginalization. In an article in Crime Prevention Digest, Ruiz blamed sensationalist newspaper reports, police mass arrests, job discrimination, segregated schools, lack of recreational opportunities, and "racial theories imported from the deep South" as the chief causes of juvenile delinquency. ${ }^{90}$ He made recommendations to the city, including opening indoor school gyms for recreation at night and on weekends; providing athletic equipment, lockers, and organized programs at recreation centers; hiring Spanish-speaking supervisors for playgrounds and recreation centers; and establishing more youth leadership camps.

In September 1940 Ruiz made his first attempt to restore relations between MAASC and the city recreation department. In a letter to Superintendent Hjelte, Ruiz acknowledged that "certain past misunderstandings have occurred between the Mexican Athletic Association and particular individuals employed by the Department of Playground and Recreation." Now, however, MAASC members expressed a desire to put these past issues aside and refocus on combatting juvenile delinquency through recreation. Ruiz proposed, "For the purpose of eliminating future confusion, to designate one or two persons from its group, as clothed with the authority of dealing with your department." Ruiz couched his argument in the rhetoric of the Good Neighbor Policy, stating that this new relationship would "foster goodwill and a spirit of international cooperation between Latin Americans and other elements of our body politic." 91

In July 1941 Ruiz was appointed executive secretary of the Coordinating Council for Latin American Youth (CCLAY). In this new leadership role, he continued to work closely with MAASC, espe-

89. Laura Gomez, "From Barrio Boys to College Boys: Ethnic Identity, Ethnic Organizations, and the Mexican American Elite: The Cases of Ernesto Galarza and Manuel Ruiz, Jr." (Stanford Center for Chicano Research, Working Paper Series No. 25, 1989), 16-17.

90. Manuel Ruiz, Jr., "Latin American Juvenile Delinquency in Los AngelesBomb or Bubble?" Crime Prevention Digest, 1 (Dec. 1941), 1-10.

91. Ruiz to George Hjelte, Sept. 4, 1940, folder 14, box 4, MO295, Ruiz Papers. 
cially raising funds to send athletes to compete in Mexico. ${ }^{92}$ Under the administration of President Manuel Avila Camacho, MAASC athletes were invited to compete in Los Juegos Deportivos Nacionales de la Revolución (National Sports Games of the Revolution, or the Revolutionary Games) between November 4 and 20, 1941. To celebrate the thirty-first anniversary of the Mexican Revolution, President Camacho instructed Mexico's physical education department to organize a two-week sports festival modeled after the Olympic Games, with over twenty-five sporting events for amateur athletes. Each Mexican state sent a delegation to participate in the Revolutionary Games, along with a México de afuera delegation from Los Angeles. CDM's representative in Mexico City, Guillermo Eddy, sent a special invitation to MAASC athletes, stating that "they will be welcomed and treated as if they were from another state in the Republic of Mexico." ${ }^{93}$ According to Eddy, CDM offered to pay for round-trip railroad transportation from Nogales to Mexico City, lodging at the Olympic Village, and food for twenty-two athletes. To raise money for transportation from Los Angeles to Nogales, MAASC partnered with CCLAY to organize a special fundraiser at the Eastside Arena. The event featured four amateur boxing matches and five professional exhibition matches that included Kid Azteca, Rodolfo Ramirez, Ricardo Lemos, and Juan Zurita, with Bert Colima acting as referee. ${ }^{94}$ In a request for a boxing permit from the State Athletic Commission, CCLAY stated that "Funds are being raised to send a goodwill athletic team to Mexico City . . . in keeping with the Federal policy of fomenting close Inter-American relations for better Pan-American solidarity." 95 After receiving approval, the boxing event generated enough funds to subsidize the travel of a basketball team, a track-and-field team, four amateur boxers, three tennis players, a coach, and a MAASC official. The transnational connections with the Mexican government strengthened MAASC's argument that more recreational

92. CCLAY was comprised of city and county officials, law enforcement and probation officers, and middle-class Mexican American professionals.

93. Dirección General de Educación Física, Juegos Deportivos Nacionales de la Revolución: Reglamento y Programa General (Mexico City, 1941), 12-13. San Antonio La Prensa, Oct. 18, 1941, p. 7.

94. La Opinión, Oct. 29, 1941, p. 7.

95. Coordinating Council for Latin American Youth to State Athletic Commission, Oct., 20, 1941, folder 14, box 4, MO295, Ruiz Papers. 
opportunities for Mexicans and Mexican Americans were urgently needed, not only for delinquency prevention but also to foster hemispheric solidarity.

Despite improved relations between MAASC and city recreation officials, a close examination of the city's Playground and Recreation Commissioners' minutes reveals recurring confrontations between Mexican American youths and European American supervisors at the city's playgrounds. At Evergreen Playground, a group of Mexican American youth submitted a petition demanding the termination of the playground director. After investigating the matter, Ruiz found that "several younger groups of boys were very dissatisfied with the present personnel and would not attend the playground at all, they would rather hang out across the street in a little lunch stand where beer and wine is sold." ${ }^{96}$ Ruiz blamed the director for "raising the juvenile delinquency rate in the district" and requested hiring more Mexican American playground supervisors. The LADPR commissioners disagreed, however, attributing the playground conflict to "Mexican misconduct" and "Mexicans causing trouble." Another playground supervisor reported that "He found it necessary to eject a Mexican boy from the gymnasium for continued misconduct." Instead of addressing the root causes of "juvenile delinquency" and hiring Mexican American supervisors, city playground directors racialized these incidents as a "Mexican Gang Problem." 97

MAASC struggled to sustain its sports programming amidst the Sleepy Lagoon court case and Zoot Suit riots, but persistent financial problems and limited access to municipal playgrounds, combined with several members enlisting into the U.S. military, made it difficult to sustain organizational unity. During wartime absences, MAU gained momentum by offering sports programming to Mexican-origin youth. Furthermore, in 1942 CCLAY began to supersede the work of MAASC by forming an athletic committee to provide additional recreational opportunities for Mexican American youth. One last attempt to revive MAASC occurred in September 1945 when returning veterans Juan Acevedo,

96. "Petition," Feb. 1942, in ibid.; Coordinating Council for Latin American Youth to Manuel Ruiz, March 9, 1942, in ibid.

97. Records of the Board of Playground and Recreation Commissioners Minutes, Dec.11, 1942, folder C-0368, box 4, LADPR Records; Board of Playground and Recreation Commissioners Minutes, Oct. 9, 1942, in ibid. 
Rafael Romero, Juan Alonso, and Roberto Ortiz held a reunion at the Casa del Mexicano in Boyle Heights. They invited all interested athletes to help "reorganize the Association and reinstate sports among our youth once again." ${ }^{98}$ With only a few attending the meeting, however, some leaders decided to part ways and pursue other interests.

\section{Conclusion}

Most scholars have focused on Mexican American campaigns for fair employment, school desegregation, public housing, unionization, and civil rights, but they have ignored the transnational politics of sports in Southern California and Mexico. MAASC played a significant role in promoting and organizing sports in both México de afuera and in Mexico from the Great Depression to World War II. In a hostile climate of high unemployment, repatriation campaigns, and racial discrimination, MAASC forged an "athletic movement" by mobilizing community-based sports clubs and athletes of Mexican descent to participate in a wide variety of sports. Sport participation did more than highlight athletic talent on the playing fields. Just as importantly, it served to present a more positive image of the Mexican diaspora. For MAASC athletes, the organization also offered a training ground for political leadership and community activism. Juan Acevedo, José Arteaga, Ray Sánchez, Juan Alonso, Francisco Costello, Pedro Despart, Ralph Romero, Manuel Ruiz, Jr., and other athletes all developed important leadership skills that transferred into political and other social arenas, at least for men. MAASC, and its sports programming, was a masculine space, with men dominating at every level. Mexican American women and young girls were steered toward more socially acceptable sports like softball and tennis.

Becoming Mexican American and becoming Mexican were simultaneous occurrences within MAASC. By building transnational ties with the Mexican government and its sports federation (CDM), MAASC was able to offer more athletic opportunities to its members and, in the process, to connect them to an emerging Mexican national identity. By allowing México de afuera athletes to join Mexico's Olympic teams or to compete in other athletic events,

98. La Opinión, March 24, 1942, p. 7; ibid., Sept. 22, 1945, p. 4. 
the Mexican government sought to extend its influence into Mexican communities abroad. MAASC and its related athletic activities simultaneously raised the consciousness of a transnational mexicanidad among its members while also connecting them to a network of municipal, high school, and college sports in Southern California. By forging close ties with Mexico's sports federation MAASC positioned itself as a chief promoter of Good Neighbor relations through organized sports, thus gaining political power and a new confidence to challenge city recreation officials. MAASC demanded that the city government provide more recreational resources for Mexican-origin youth who faced segregated schooling, negative press coverage, intimidating police officials, and prejudiced city recreation officials. With or without the city's assistance, MAASC achieved some success in steering both Mexicans and Mexican Americans toward athletic, educational, and political pursuits. 
Reproduced with permission of the copyright owner. Further reproduction prohibited without permission. 